The Social Sciences 7 (5): 689-695, 2012

ISSN: $1818-5800$

C) Medwell Journals, 2012

\title{
Three Decades of The Development of Academic Journals in Islamic Studies in Malaysia 1977-2007
}

\author{
Roosfa Hashim and Hasnan Kasan \\ Center for General Studies, The National University of Malaysia, Bangi, Malaysia
}

\begin{abstract}
The intent of this study is to present the status and position of academic journals in Islamic studies in this country. The exponential growth of teaching and research institutes centralising on Islamic studies has given rise to the number of Islamic scholars in this country and prospers various research and publication endeavours. This scenario is welcome with the emergence of diverse academic journals that serve as the academic centerstage in multiple Islamic knowledge branches. The status of this journal is examined by detecting it using the library and publisher catalogues. This study documents 34 academic journals in various branches of Islamic studies and published for the past 3 decades in the period of 1977-2007.
\end{abstract}

$\underline{\text { Key words: Malaysia, scholarly publishing, scholarly journal publishing, Islamic studies, Islamic titles }}$

\section{INTRODUCTION}

The progress of higher education institutes with the core of Islamic studies in Malaysia can be said to have started with the founding of the Islamic Studies Department in Universiti Malaya in 1959 resulting from the official relationship formed between Malaya Islamic College with Universiti Malaya. Other than the Islamic Studies Department, there is the Islamic Academy in Universiti Malaya. When both work in affiliation, this births the Islamic Studies Academy, Universiti Malaya. The Islamic College Council has the role of safeguarding administration matters of the department while the Senate of Universiti Malaya monitors the academic activities. When the Islamic College Council was abandoned in 1970, the Islamic Studies Department was placed under the supervision of the Universiti Malaya Council and Senate. When combined with the Islamic Studies Academy in 1996, this department was then relocated under the Social Science and Arts Faculty, Universiti Malaya.

The Islamic Studies Academy was established in 1981 when Universiti Malaya had taken over the Kelantan Higher Education Foundation. This academy is proud to have two faculties which are the Sharia and Usuluddin Faculties and it offers Islamic education degree and the matriculation programme, Islamic pre-Academy Universiti Malaya. The matriculation programme started since 1981 after the handing over of the Kelantan Islamic Higher Education Foundation into the administration of Universiti Malaya. The Islamic pre-Academy Course serves as the main source of entry into the Syariah, Usuluddin and Islamic Education faculties.
In 1996, the academy has 9 departments, all of which are the Fiqh and Usul Department, Siasah Syar'iyyah Department, Shari'a and Economy Department, Shari'a and Management Department, Moral and Islamic Thinking Department, Human Development and Islamic Teaching Department, al-Quran and Hadith Department, Islamic History and Civilisation Department.

At the Universiti Kebangsaan Malaysia, the Islamic Studies Faculty (FPI) was established on 18th May, 1970 in tandem with the establishment of Universiti Kebangsaan Malaysia. The basis for its foundation began with the founding of Malaya Islamic College in Klang in 1955 materialising the wishes of the Muslims in this country to have an Islamic based Higher Education Institute in the country. In 1968, the Ministry of Education had agreed to elevate the status of Malaya Islamic College to the college university status. When the Universiti Kebangsaan Malaysia was established, the Islamic College was included under the UKM as one of the faculties, together with other two faculties at the time which are the Science and the Arts Faculty. To date, the Islamic Studies Faculty has 5 departments namely; the Shari'a Department, Usuluddin and Philosophy Department, Arabic Studies and Islamic Civilisation Department, Islamic Studies and Leadership Department also al-Quran and Sunnah Studies Department.

The Islamic Contemporary Studies Faculty (FKI), Universiti Darul Iman Malaysia (UDM) had its establishment endorsed by the Higher Education Ministry (KPT) starting from July, 2006 into the Higher Education Committee meeting code 9/2006 on 19 December, 2006. This faculty serves as a combination of three schools

Corresponding Author: Roosfa Hashim, Center for General Studies, The National University of Malaysia, Bangi, Malaysia 
during the era of Kolej Ugama Sultan Zainal Abidin (KUSZA) or Sultan Zainal Abidin Islamic College namely Islamic Studies School (SPI), General Studies School (SPU) and the Education Studies School (SPP). The combination of three main fields Islamic Studies, Social Science Studies and education are anticipated to be able to solidify these related fields, especially those associated with contemporary issues.

Up until 2008, FKI was headed by a dean assisted by 2 deputies and 6 heads of the department. The departments approved by the FKI endorsed by the UDM Senate are the Shari'a, Usuluddin, Islamic Teachings, al-Quran and al-Sunnah, Social Science and Islamic Education and Civilisation Departments.

With the progress that has been mentioned earlier, it is clear that a drastic improvement has been noted in the number of Islamic studies scholars in this country. With the increasing number of universities, faculties and departments that make Islamic studies their core subjects, automatically the number of Islamic based research also escalates. Therefore, the demands for publication media in the form of academic journals are also increasing.

The academic journals of Islamic studies need to grow in line with the increasing number of institutions as the scholars need to illustrate great contributions in the publication to prove that they are competent and can perform well in their own respective careers. The performance of a scholar is measured through the total amount of academic publication that he or she has produced. What is the status of the academic journal publication among Islamic studies scholars in this country? Is there any progress in various fields and sub-fields of the Islamic studies? What is the institution that has been active in publishing Islamic studies academic journals? What is the position of Bahasa Melayu in this stream of development? What is the quality of the publication that has distributed these journals?

\section{DETAILING THE DEVELOPMENT OF ACADEMIC JOURNALS}

A lot of studies have been done on the development of academic journals in certain fields. Tiew (1998), for example, examines the progress of JMBRAS between 1878-1997 in another study, he looks at the movement of academic journals publications in the field of history (Tiew, 2003). In this study, he reviews the earliest journal published in 1847. Roosfa in turn, examines the advancement of the translators journal or Journal Psikologi Malaysia, the 10 year progress of Journal
Filologi Melayu, the 30 year development of the Journal Akademika, the Movements of Scientific Journals in Malaysia and at the UKM (Hashim, 2002).

On the journals' visibility at the international level, Ngah (1997) has made the effort to look at this aspect. The issue of accepting our scholars to publish their study in the electronic journals has been unravelled by Ding and Suhaimi and also by Hashim (2002). Yet up to this extent, there are yet to be writers or researchers who take a close look and examine the growth of academic journals in the field of Islamic studies. This is the gap that this study has attempted to fulfill.

\section{EARLY ISLAMIC STUDIES JOURNAL}

Although, the Islamic Studies Department at the Universiti Malaya had been birthed back in 1959, no academic journal has been detected in the Islamic studies discipline as early as the time when the department was founded. Contrastingly, the earliest academic journals in Islamic studies started to emerge in the Universiti Kebangsaan Malaysia, named Islamiyyat which publication started in 1977. It is safe to say here that the publication of academic journals in Islamic studies had been behind time in this country.

By contrast at the Universiti Malaya, the earliest detection of academic journals at the Islamic Studies Academy in 1988 had been noted in the journal entitled Medium MajalahElmiah Akademi Islam Universiti Malaya. From the title which did use the word magazine (or Majalah), it is a strong point to say that there was yet to be the likelihood towards publishing Islamic studies journals at this oldest university campus in Malaysia. Islamiyyat is now published by the Universiti Kebangsaan Malaysia Publisher. This journal is published in Bahasa Melayu, English and Arabic, twice in a year. The articles published cover all the fields of Islamic studies and from other fields written from other perspectives of Islam.

\section{THE GROWTH OF ISLAMIC STUDIES JOURNAL}

All in all, this study has managed to document as many as 34 academic journals in various branches of Islamic studies in the period of 30 years, between 1977-2007. In these 3 decades, only 1 journal namely the Islamiyyat publication journal in the $70 \mathrm{~s}, 10$ journals in the $80 \mathrm{~s}, 13$ in the $90 \mathrm{~s}$ and 10 in the new millenium that is after the year 2000 (Table 1).

This total number of 34 journals are based on the adoption of the title used at the time when the study was 
The Soc. Sci., 7 (5): 689-695, 2012

Table 1: The Islamic studies academic journals publication following the duration of 10 y ears

\begin{tabular}{lc}
\hline Decades & Total number of new joumals published \\
\hline $1970 \mathrm{~s}$ & 1 \\
$1980 \mathrm{~s}$ & 10 \\
$1990 \mathrm{~s}$ & 13 \\
$2000-2007$ & 10 \\
Total & 34 \\
\hline
\end{tabular}

Table 2: Language used in the articles

\begin{tabular}{lc}
\hline Languages & Articles \\
\hline Bahasa Melayu & 14 \\
English & 6 \\
Bahasa Melayu and English & 7 \\
Bahasa Melayu, English and Arabic & 6 \\
Arabic & 0 \\
Total & 34 \\
\hline
\end{tabular}

first conducted. Some may have been aware of the fact that some journals have had to change their titles before maintaining a particular name. For example, the IIUM law journal originally was entitled journal of Islamic economics. Other than that, journal of Islamic economics and management when ended was continued as IIUM journal of economics and management (Appendix).

\section{THE WRITTEN LANGUAGE}

This study explores the use of language in the academic journals of the Islamic studies published in this country. The Islamic studies field is often linked with the use of Arabic. Mastery in Arabic is a skill that is highly regarded by scholars who are involved in this field. However, any Islamic studies journal simply cannot be discerned in this country where the journals have used Arabic throughout the journals. Most of the 34 journals which are able to be documented in this study use Bahasa Melayu (in 14 journals) whereas the remaining would use either full English (6), Bilingual which is Bahasa Melayu and English ( 7 journals) or using all 3 languages Bahasa Melayu, English and Arabic (6 journals) (Table 2).

\section{PUBLISHER JOURNAL PENGAJAN ISLAM}

Academic journals are publication work which contains only writings produced from research done and recorded. With that, academic journals are only written and read by expert scholars in their respective fields. The Islamic studies field is not exempted from this condition. The number of printing and sale of academic journals have been somewhat low. Therefore, the private sector has not placed too great an interest on publishing academic journals as it will not bring in any profit. In turn, academic journals are only published by the university
Table 3: The publication of academic journals of Islamic studies by institution

\begin{tabular}{lc}
\hline Institutions & No. of journals \\
\hline University & 7 \\
UM & 4 \\
UKM & 4 \\
UIA & 3 \\
USIM/KUIM & 3 \\
UiTM/ITM & 2 \\
KUSZA & \\
Public agencies & 3 \\
JPM & 2 \\
IKIM & 1 \\
JAKIM & 1 \\
YADIM & 1 \\
JAIM & 1 \\
Judicial department & \\
NGO/private & 1 \\
ABIM & 1 \\
UMNO & 34 \\
Total & \\
\hline
\end{tabular}

Table4: Journal of Islamic studies by knowledge sub-field

\begin{tabular}{lc}
\hline Fields & Journals \\
\hline Islamic studies/general studies & 19 \\
Law, Shari'a & 6 \\
Economy, Finance & 3 \\
Philosophy, Thinking & 2 \\
Fiqh, Usuluddin & 2 \\
Civilisation & 1 \\
Fatwa & 1 \\
Total & 34 \\
\hline
\end{tabular}

publisher, faculty and academic department, government department, scholars' associations and stake holders like the non-governmental bodies (Table 3 ).

\section{THE DEVELOPMENT OF SUB-FIELDS OF ISLAMIC STUDIES}

It can be said that most journals (19 of them) in the Islamic studies published in this country are journals that are general by nature where it only accumulates any articles related to the field of Islamic studies. About 19 $(55 \%)$ is actually a big figure. Only $6(17 \%)$ are journals from the fields of law or Shari'a, 3 (8\%) in Economy and Finance, 2 in Philosophy and Thinking and Fiqh and Usuluddin, respectively. Only 1 journal in civilisation and another journal in then field of Fatwa (Table 4).

\section{THE ISLAMIC STUDIES ACADEMIC JOURNAL PUBLICATION QUALITY}

Like academic journals in other fields, Islamic studies journals also have to confront similar problems so much so that the publication quality suffers. The level of professionalism among the editors are also taking the backseat. They are not exposed to the formal publication 
training. The exposure received is only based on the experiences and errors that have been committed when being involved in the particular faculty or department's journal publications.

This low professionalism level can be observed on several basic aspects. An example is from 34 academic journals that are documented with only 22 having the ISSN number. About 12 journals do not have ISSN number, a number that is considerably high. Only 4 journals $(12 \%)$ are published twice a year while the rest (30 journals) published once a year. This illustrates the low level of capability among the Islamic studies academicians to publish academic journals. For the large part of the Islamic studies journals, the publication company has also failed to follow the publication schedule.

From 34 academic journals of Islamic studies published in this country, only two $(5 \%)$ have been enlisted in the index database and international abstracts. The said journals are the IIUM law Journal enlisted in EconLit.e-JEL, JEL (dlm. CD), Asian Pacific Economic Literature, Index of Islamic Literature. Another journal namely Intellectual Discouse: The Journal of the Faculty (Kulliyah) of Islamic Reveal Knowledge and Human Sciences is included in LISAPlus.

Journals enlisted in various index services and international abstracts are of course more visible compared to Islamic studies journals that have become their rivals. To improve on visibility, journals make the initiative to create their own websites and this is apparent in an example, the IIUM Journal of economics and management (www.iiu.edu.my/enmjournal/).

\section{CONCLUSION}

Several conclusions can be derived from the study outcome. First of all, there has been a rather fast paced growth in academic journal publications in Islamic studies since Islamiyyat was published in 1977. Secondly, there has been no extensive development in the certain knowledge sub-fields under Islamic studies. The majority of journals published come in various general fields of the Islamic studies. Thirdly, the university emerges as a party that has published a great deal of academic journals in Islamic Studies. Universiti Malaya is the university that has published such journals the most. Fourthly, the visibility of academic journals of Islamic studies published in this country is low. Only 2 journals are in the list of the index services and international abstracts and only 1 has a website. Fifth, Bahasa Melayu is prominent as the major language used in the academic communication of the Islamic studies field. English and Arabic are used as additonal languages. Sixth, the professionalism level of the academic journal publication in the field of Islamic studies has also been low. Several prominent weaknesses are also exposed rather easily, for instance, the non-existent ISSN number.

This study is an initial effort to monitor the development and growth of academic journals in the Islamic studies field. In the future, it is probably a wise move to conduct more profound studies. Among these, studies which are bibliographical by nature for analysing the contributions of certain scholars in the construction of the knowledge corpus in certain fields can be done. Also, an equally good idea is for future studies to look at the trend that can be shown on the knowledge movement that is taking place as the outcome of the research done by the scholars and researchers in the area of Islamic studies.

\section{APPENDIX}

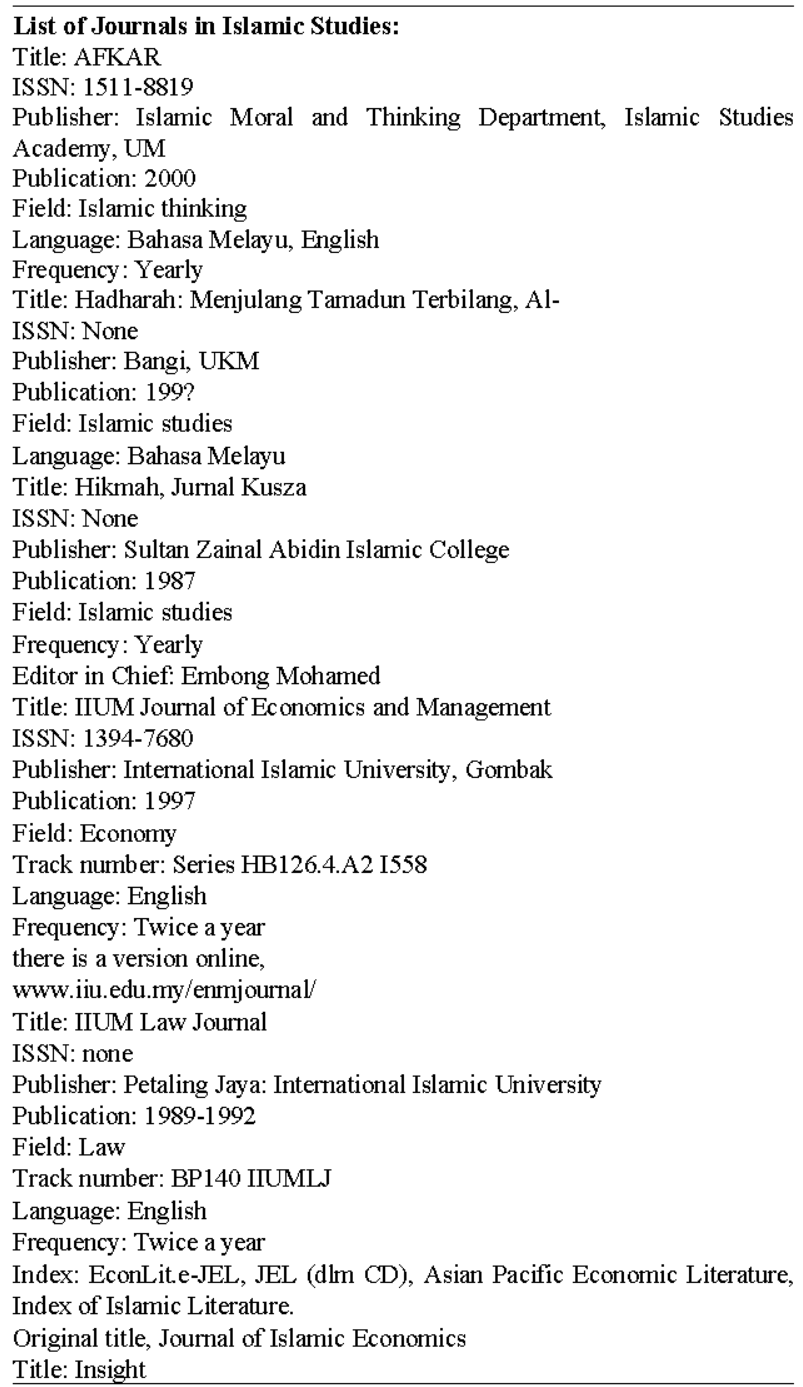


The Soc. Sci., 7 (5): 689-695, 2012

Appendix continue

ISSN: 1394-133X

Publisher: Petaling Jaya: Faculty of Economics and Management, International Islamic, IIUM

Publication: 1995

Field: Law

Track number: HB1 INS

Language: English

Frequency: Yearly

Title: Intellectual Discouse: The Joumal of the Faculty (Kulliyah) of Islamic

Revealed Knowledge and Human Sciences

ISSN: 0128-4878

Publisher: Research Centre, Intemational Islamic University Press Malaysia Publication: 1993

Field: Islamic studies, Humanity

Index: LISAPlus

Language: English

Frequency: Yearly

Title: Islamiyyat

ISSN: 0126-5636

Publisher: Bangi: Fakulti Pengajian Islam, Universiti Kebangsaan Malaysia Publication: 1977 - 2007

Field: Islamic studies

Track Number: Series BP1.I84 8

Language: Bahasa Melayu, English, Arabic

Frequency: Yearly

This journal is published to fulfill the research requirements in the Islamic Studies Faculty in UKM and open to writers and researchers from outside

UKM. The article is published in Bahasa Melayu, English and Arabic.

Title: Isu Syariah dan Undang-Undang

ISSN: $1511-3434$

Publisher: Bangi: Fakulti Pengajian Islam, Universiti Kebangsaan Malaysia

Publication: 1996

Field: Law

Track number: Series BP140 .I885 2

Language: Bahasa Melayu

Frequency: Yearly

Title: Jernal Hukum

ISSN: none

Publisher: Kuala Lumpur: Malaysia Shari'a Judicial Department Malaysia

Publication: 1980-present

Field: Law

Language: Bahasa Melayu, English

Frequency: Yearly

Title: Jernal IKIM

ISSN: none

Publisher: Kuala Lumpur: Malaysia Islamic Understanding Institute

Publication: 1993

Field: Islamic Studies

Language: Bahasa Melayu, English

Frequency: Yearly

Title: Journal of Islamic Economics and Management

ISSN: none

Publisher: Petaling Jaya: Kulliyyah of Economics, Intemational Islamic

University, Malaysia

Publication: 1988-1996

Field: Economy

Language: English

Frequency: Yearly

This journal is ended and restarted with the Title IIUM Journal of

Economics and Management.

Title: Journal of Muamalat in Finance Research

ISSN: $1823-075 \mathrm{X}$

Publisher: USIM

Publication: 2004

Field: Finance
Apendix continue

Track number: Series HG187.4.J6

Language: English

Frequency: Yearly

Title: Journal CITU (Centre for Islamic Thought and Understanding)

ISSN: $1394-8377$

Publisher: Centre for Islamic Thought and understanding, UiTM

Publication: 2005

Field: Islam, Philosophy

Language: Bahasa Melayu, English

Frequency: Yearly

Editor- in Chief: Zaharah Yahya

The CITU joumal is a journal due to be published twice a year by the Centre for Islamic Thought and Understanding (CITU), UiTM. The main purpose of this journal is to prepare a channel for publishing academic works in the form of research, articles, reviews with regards to culture, social, economy, politics, education and others including current issues, local and abroad.

Title: Journal Dakwah

ISSN: None

Publisher: Kuala Lumpur: Biro Dakwah Pergerakan Pemuda UMNO Malaysia

Publication: 1983

Field: Religion

Track number: BP1 JD

Language: Bahasa Melayu

Frequency: Yearly

Publication ended in 1987

Title: Journal Darul Quran

ISSN: $1394-391 \mathrm{X}$

Publisher: Jabatan Kemajuan Malaysia

Publication: 2006

Field: Islam

Language: Bahasa Melayu

Frequency: Yearly

Editor In Chief: Mohamad Murni Awang Mat

The magazine called Journal Darul Quran 10th edition continues to maintain the sequence of objectives and role in highlighting discussions that cover various issues associated with the al-Quran other than shedding light on the Quran an invaluable treasure to mankind in this world and in the afterlife. Title: Jumal Fikrah

ISSN: $1511-1113$

Publisher: Islamic Education Unit, Preparatory Education Center, ITM Shah Alam

Publication: 1998

Field: Islamic studies

Track number: Series BP144.J8 kat

Language: Bahasa Melayu

Frequency: Yearly

Price: RM 15

Editor in Chief: Mohamed Azam Mohamed Adil

According to the Editor In Chief, Journal Fikrah is birthed to improve the quality of knowledge as a fraction of the academics. Without writing and research, one cannot simply be called a lecturer if he only comes to the lectures to give a lecture but they must show the quality of the lecture through knowledge improvement.

Title: Journal Fiqh = Journal of Fiqh

ISSN: $1823-089 \mathrm{X}$

Publisher: Department of Fiqh and Usul Academy of Islamic Studies, University of Malaya

Publication: 2004

Field: Fiqh and Usuluddin

Language: Bahasa Melayu, English, Arabic

Frequency: Yearly

Editor In Chief: Idris Awang

This joumal has become the media in addressing contemporary issues in the 
The Soc. Sci., 7 (5): 689-695, 2012

Apendix continue

knowledge branch of fiqh, other than becoming the database for Islamic studies. The journal committee comprises of Mahmood Zuhdi (Universiti Malaya), Abdul Samat Musa (Islamic College University of Malaysia), H.M. Yasin Nasution (INN Sumatera Utara), Mat Saat Abdul Rahman (UBD Brunei) and Hassan Madmarn (PSU Thailand)

Title: Jurnal Hukum

ISSN: none

Publisher: Islamic Affairs Department, Prime Minister department

Publication: 1980

Field: Law

Title: Jumal IKIM

ISSN: None

Publisher: Islamic Understanding Institute Malaysia (IKIM)

Publication: 1993

Field: Islam

Title: Jumal Pendidikan Islam (ABIM)

ISSN: 9090-060X

Publisher: Kuala Lumpur: Angkatan Belia Islam Malay sia

Publication: 1983

Field: Islamic Studies

Track Number: Series LC901.J87

Editor In Chief: Zawawi Hj. Ahmad

Language: Bahasa Melayu, English

Frequency: Yearly

Title: Jumal Pengurusan dan Penyelidikan Fatwa

ISSN: $1675-5936$

Publisher: World Fatwa Research and Management Institute, USIM

Publication: 2007

Field: Islam, Fatwa

Language: Bahasa Melayu, English and Arabic

Frequency: Yearly

Title: Jurnal Peny elidikan Islam

ISSN: none

Publisher: Islamic Affairs Department, Prime Minister Office

Publication: 1986-1995

Field: Islamic studied

Track number: BP1 MA / BP1 JPI

Language: Bahasa Melayu

Frequency: Yearly

Title: Jurnal Peradaban

ISSN: ?

Publisher: Universiti Malaya Civilisation Dialogue Center

Publication: ?

Field: Civilisation

Language: English and Bahasa Melayu

Frequency: Yearly

This journal is printed by the Universiti Malaya Publisher on behalf of the Universiti Malaya Civilisation Dialogue Center

Title: Journal Syariah $=$ Shariah Journal

ISSN: 0128-6730

Publisher: Islamic Studies Academy, Universiti Malaya

Publication: 1993

Field: Islamic law, politics, muamalat, Islamic economy, Islamic management, thinking

Track Number: 2 Series KQB.U65

Language: Bahasa Melayu, English

Price: RM 20

Frequency: Twice a year

Journal Syariah has the objective to develop and improve Shari'a studies by stressing on the the fields of Islamic law, legislation, politics, muamalat, economy, contemporary management and thinking. This joumal is supported by a panel of editors comprising of Mahmood Zuhdi Ab. Majid (Ketua), Abdul Monir Yaacob, Ab. Mumin Ab. Ghani, Ahmad Hiday at Buang, Paizah Ismail, Idris Awang dan Suwaid Tapah.

Title: Journal Tasawwur Islam

Publisher: Melaka: Jabatan Agama Islam Melaka (JAIM)
Apendix continue

ISSN: 0128-8970

Publisher: UiTM

Publication: 1994

Field: Islam

Track Number: BP1 TI

Language: Bahasa Melayu

Frequency: Yearly

Title: Journal Usuluddin = Joumal of Usuluddin

ISSN: $1394-3723$

Publisher: Usuluddin Studies Department, Islamic Studies Department,

Universiti Malaya

Publication: 1993

Field: Islamic studies, Usuluddin

Track number: Series BP145.J73 kat

Language: Bahasa Melayu, English, Arabic

Price: RM 20

Frequency: Twice a year

This journal contains articles related to Islamic moral and thinking, AlQuran and Hadith studies, Islamic History and Civilisation, Islamic teachings and human development.

Title: Journal YADIM

ISBN: $1511-905 \mathrm{X}$

Publisher: Malaysia Dakwah Islamiyah Foundation

Publication: 2001

Field: Islamic studies

Track Number: Series BP1 .J87 kat

Language: Bahasa Melayu

Frequency: Yearly

Editor In Chief: Haji Kamaluddin M. Zin

This journal is published to spread true teachings on the right path. Muslims get to be provided with relevant, autonomous articles, touching on current issues prevalent in the society. Academic materials as well as in-depth studies on community issues are crucial to be spread, to reject any confusion and misunderstanding that can arise among Muslims today.

Title: Masa

ISSN: 1026-916X

Publisher: Islamic Research Center Malaysia, Baheis.

Start of Publication: 1980

Field: Islam

Title: Mawizah, Al-

ISSN: none

Publisher: Islamic studies Faculty, UKM

Start of Publication: 199 ?

Field: Islamic Studies

Language: Bahasa Melayu, English, Arabic

Frequency: Yearly

Is ended

Title: Medium: Majalah Elmiah Akademi Islam Universiti Malaya

ISSN: 9093-7082

Publisher: Universiti Malaya Islamic Studies Academy

Publication: 1988

Field: Islamic studies

Track number: BP1 ME

Language: Bahasa Melayu

Frequency: Not constant

Title: Mizan, Al-

ISSN: 1675-1523

Publisher: Sultan Zainal Abidin Islamic College

Publication: 2003

Field: Islamic Studies

Language: Bahasa Melayu

Frequency: Yearly

Title: Tasawwur Islam: Jurnal Perspektif Islam

ISSN: 0128-8970

Publication: 1994 
Apendix continue

Field: Islamic studies

Track number: BP1 TI

Language: Bahasa Melayu

Frequency: Yearly

Title: Ulum Islamiyah/The Malaysian Journal of Islamic Sciences Islamic

University College of Malaysia.

ISSN: $1675-5936$

Publisher: Kolej Universiti Islam Malaysia (KUIM)/Islamic University College of Malay sia

Publication: 2002

Field: Islamic studies

Track number: Series BP1.U485

Language: Bahasa Melayu, English, Arabic

Frequency: Yearly

Editor In Chief: Prof. Dr. Muhamad Muda

Ulum Islamiyyah is an annual journal published by the Islamic University College Malaysia. The main objective of its publication is to produce an information channel for the publications of original articles, study notes case studies and book reviews based on studies, researchers original thoughts also commentaries in the Islamic studies and related materials. All articles will be revised through the double-blind review by an independent editor. The board of editor has the right to edit the materials.

\section{REFERENCES}

Hashim, R., 2002. The development of science, technology and medical scholarly journals in Malaysia, 1890-2002. Proceedings of the 11th International Conference for Science Editors, August 24-28, 2002, Beijing. China.

Ngah, Z.A., 1997. The coverage of Malaysian scholarly journals by international indexing and abstracting services: An assessment of their visibility and common characteristics. Malaysian J. Library Inform. Sci., 2: 13-30.

Tiew, W.S., 1998. History of journal of the malaysian branch of the royal asiatic society (JMBRAS) 18781997: An overview. Malaysian J. Lib. Inform. Sci., 3: $43-60$.

Tiew, W.S., 2003. Malaysian historical journals (18471966): A bibliometric study. Malaysian J. Library Inform. Sci., 8: 19-43. 